\section{Gibberellin Applications Influence the Scheduling and Flowering of Limonium x 'Misty Blue'}

\author{
James M. Garner \\ Department of Horticulture, Auburn University, Auburn, AL 36849
}

\author{
Allan M. Armitage \\ University of Georgia, Department of Horticulture, Athens, GA 30602
}

Abstract. Limonium x 'Misty Blue' plants were treated with directed sprays of gibberellic acid $\left(G_{3}\right)$ at $400 \mathrm{mg}$ liter ${ }^{-1}$ at weekly intervals. All $\mathbf{G A}_{3}$ treatments accelerated flowering and increased yield of flowering stems compared to nontreated plants. Treatment at 4 weeks after planting resulted in the greatest acceleration of flowering and increase in stem yield.

In recent years, Japanese breeders have introduced several new Limonium hybrids suitable for cut-flower production. New hybrids of the caspia type $[L$. latifolium $(\mathrm{Sm}$.) $\mathrm{O}$. Kuntze $x$ L. bellidifolium (Gouan) Dumort.] appear to be highly productive and well adapted to protected cultivation (Armitage, 1993). Flowering of Limonium x 'Misty Blue' may require 3.5 to 4 months from the time of planting, and reported yields average six to seven stems per plant in the first year and 10 or more in the second year (New World Plants, 1992). Acceleration of flowering and enhancement of first-season yield in this crop would be desirable, allowing growers to reduce crop inputs and increase production efficiency.

Applications of gibberellic acid $\left(\mathrm{GA}_{3}\right)$ at $500 \mathrm{mg} \cdot$ liter $^{-1}$ can reduce time to flowering in Limonium sinuatum (L.) Mill. (Wilfret and Raulston, 1975). Gibberellin partially replaces vernalization requirements, thereby reducing precooling requirements (Shilo and Zamski, 1985). However, efficacy of this type of growth regulator application depends on application timing (Wilfret and Raulston, 1975). Flowering in Limonium is promoted by long days and low temperatures (Semeniuk and Krizek, 1972), and response to gibberellin applications also seems to be related to cumulative exposure to cold days and photoperiod (Shilo, 1977). Wilfret and Raulston (1975) reported that gibberellin substituted for cold under longday conditions but was less effective under short-day conditions. Additionally, $\mathrm{GA}_{3}$ was ineffective on plants that had not been exposed to low temperatures or in which vernalization had been saturated (Shilo, 1977). Proper timing of $\mathrm{GA}_{3}$ applications under cool, long-day conditions may optimize the flowering re-

Received for publication 8 May 1995. Accepted for publication 22 Nov. 1995. Many thanks to Fred Myer and New World Plants for their assistance in this study. The cost of publishing this paper was defrayed in part by the payment of page charges. Under postal regulations, this paper therefore must be hereby marked advertisement solely to indicate this fact. sponse. Our objectives were to evaluate the influence of exogenous $\mathrm{GA}_{3}$ applications on flowering of Limonium X 'Misty Blue' and to determine optimum application timing to enhance flowering response.

\section{Materials and Methods}

On 10 Dec. 1993, tissue-cultured liners of Limonium $\mathrm{x}$ 'Misty Blue', obtained from New World Plants, Escondito, Calif., were planted in a glass greenhouse with a minimum setpoint of $8 \mathrm{C}$. Plants were set in ground beds filled to a depth of $25 \mathrm{~cm}$ with a commercial soilless medium (Fafard Growing Mix no. 3B; Conrad Fafard, Agawam, Mass.) that was amended with a slow-release fertilizer $(18 \mathrm{~N}-3.8 \mathrm{P}-9.9 \mathrm{~K}$; Osmocote; Grace-Sierra Co., Milpitas, Calif.) at $5 \mathrm{~kg} \cdot \mathrm{m}^{-3}$. Planting density was five plants/ $\mathrm{m}^{2}$.

Plants received night-break lighting (from 1000 to $0200 \mathrm{HR}$ ) with $60-\mathrm{W}$ incandescent lamps to provide $\approx 5 \mu \mathrm{mol} \cdot \mathrm{m}^{-2} \cdot \mathrm{s}^{-1}$ at plant level throughout the experiment. Plants were watered manually, and supplemental, soluble fertilizer applications of $15 \mathrm{~N}-0 \mathrm{P}-12.5 \mathrm{~K}$ (Peters Dark Weather Feed, Grace-Sierra Co.) were made weekly with $\mathrm{N}$ at $250 \mathrm{mg} \cdot \mathrm{liter}^{-1}$. A grid of support netting was suspended $65 \mathrm{~cm}$ above the bed surface and was maintained throughout the experiment.

Although randomizing treatment groups in the greenhouse was accomplished, microclimates differed. To reduce the effect of these 'Misty Blue'. (group 5).

*Significant within rows at $P \leq 0.05$. differences, a control was included with each $\mathrm{GA}_{3}$ treatment. Plants were divided into five groups, each consisting of 18 single-plant replications; these replications were subdivided into nine treated plants and nine nontreated controls. One nine-plant group received a single $\mathrm{GA}_{3}$ application, and only water was applied to the remaining nine plants in that group. Plants, treated at $\approx 10$-day intervals, received a directed spray of $\mathrm{GA}_{3}$ at $400 \mathrm{mg} \cdot \mathrm{liter}^{-1}$, applied in 10-ml aliquots per plant and equivalent to 4 $\mathrm{mg} \mathrm{GA}_{3} /$ plant. The solution was applied to the growing crown of the plant, and shields were used to eliminate spray drift to the growing medium or adjacent plants. Applications were made on 21 Dec. 1993 (group 1) and 3 (group 2), 13 (group 3), and 23 Jan. (group 4) and 2 Feb. 1994 (group 5).

Stems were harvested at a commercially accepted stage of maturity for Limonium, or when $\approx 80 \%$ of the inflorescence was mature (Armitage, 1993). Stems were cut to allow 2 to $3 \mathrm{~cm}$ of the stem base to remain on the plant, and overall cut-stem length was recorded. All stems were harvested to determine yield, and time to cutting for the first 10 stems from each treatment group was used to determine flowering acceleration attributable to gibberellin. Harvest data were collected from onset of flowering until 7 June 1994. Data were tested by analysis of variance, and means were separated by Duncan's multiple range test at $P \leq$ 0.05

\section{Results}

$\mathrm{GA}_{3}$ application accelerated flowering in all groups compared to nontreated control plants (Table 1). The range of accelerated flowering was $8.7 \%$ for group 4 to $13.5 \%$ for group 2 . The average acceleration for all treatments was 17.2 days $(11.5 \%) . \mathrm{GA}_{3}$ application at 33 days from planting (group 3 ) resulted in the highest percent acceleration of flowering, with 10 stems produced by the treated group $\approx 3$ weeks earlier than by the control.

Stem lengths and diameters in treated groups and controls were similar (data not shown), indicating that stem quality, as measured by length, was not affected by $\mathrm{GA}_{3}$. Plants and stems were similar in appearance in treated and control groups.

Total stem yield was higher in $\mathrm{GA}_{3}$-treated plants than in controls only for group 1 (Table 2). Yields among treated groups ranged by a factor of nearly two.

Table 1. Effect of gibberellic acid $\left(\mathrm{GA}_{3}\right)$ application timing on acceleration of flowering of Limonium $\mathrm{x}$

\begin{tabular}{|c|c|c|c|c|}
\hline \multirow[b]{2}{*}{ Group ${ }^{z}$} & \multirow{2}{*}{$\begin{array}{l}\text { Days from planting } \\
\text { to } \mathrm{GA}_{3} \text { application }\end{array}$} & \multicolumn{2}{|c|}{$\begin{array}{l}\text { Mean days to } \\
\text { first } 10 \text { stems }\end{array}$} & \multirow{2}{*}{$\begin{array}{c}\% \text { Acceleration } \\
\text { (treatment vs. control) }\end{array}$} \\
\hline & & $\mathrm{GA}_{3}$ & Control & \\
\hline 1 & 9 & $142 \mathrm{c}^{\mathrm{y}}$ & $161 \mathrm{~b}^{*}$ & 12.6 \\
\hline 2 & 22 & $146 \mathrm{c}$ & $164 \mathrm{ab}^{*}$ & 11.9 \\
\hline 3 & 33 & $146 \mathrm{c}$ & $166 \mathrm{ab}^{*}$ & 13.5 \\
\hline 4 & 42 & $153 \mathrm{~b}$ & $167 \mathrm{ab}^{*}$ & 8.7 \\
\hline 5 & 52 & $162 \mathrm{a}$ & $179 \mathrm{a}^{*}$ & 10.6 \\
\hline
\end{tabular}

${ }^{\mathrm{z}} \mathrm{GA}_{3}$ applied 21 Dec. 1993 (group 1); and 3 (group 2), 13 (group 3), and 23 Jan. (group 4); and 2 Feb. 1994

yMean separation within columns by Duncan's multiple range test at $P \leq 0.05$. 
Table 2. Total yield of flowering stems of Limonium x 'Misty Blue'.

\begin{tabular}{|c|c|c|c|c|}
\hline \multirow[b]{2}{*}{ Group $^{2}$} & \multirow{2}{*}{$\begin{array}{l}\text { Days from planting } \\
\text { to } \mathrm{GA}_{3}{ }^{\mathrm{y}} \text { application }\end{array}$} & \multicolumn{2}{|c|}{$\begin{array}{c}\text { Mean yield/ } \\
\text { plant (no. stems) }\end{array}$} & \multirow{2}{*}{$\begin{array}{c}\% \text { Acceleration } \\
\text { (treatment vs. control) }\end{array}$} \\
\hline & & $\mathrm{GA}_{3}$ & Control & \\
\hline 1 & 9 & $4.6 \mathrm{a}^{\mathrm{x}}$ & $1.8 \mathrm{a}^{*}$ & 153.7 \\
\hline 2 & 22 & $3.0 \mathrm{~b}$ & $2.8^{\mathrm{Ns}}$ & 8.0 \\
\hline 3 & 33 & $3.5 \mathrm{ab}$ & $2.7^{\mathrm{Ns}}$ & 28.1 \\
\hline 4 & 42 & $2.8 \mathrm{~b}$ & $1.9^{\mathrm{Ns}}$ & 43.5 \\
\hline 5 & 52 & $2.4 \mathrm{~b}$ & $2.0^{\mathrm{Ns}}$ & 28.0 \\
\hline
\end{tabular}

${ }^{2} \mathrm{GA}_{3}$ applied 21 Dec. 1993 (group 1); and 3 (group 2), 13 (group 3), and 23 Jan. (group 4); and 2 Feb. 1994 (group 5).

${ }^{\mathrm{y}} \mathrm{GA}_{3}=$ Gibberellic acid.

${ }^{x}$ Mean separation within columns by Duncan's multiple range test at $P \leq 0.05$.

Ns, *Nonsignificant or significant within rows at $P \leq 0.05$, respectively.

\section{Discussion}

Exogenous $\mathrm{GA}_{3}$ applications enhanced yield of flowering stems and accelerated flowering of Limonium x 'Misty Blue'. Gibberellin may have partially satisfied vernalization requirements in this hybrid and, thereby, accelerated flowering. $\mathrm{GA}_{3}$ application made $\approx 4$ weeks after planting appeared to be optimum in terms of accelerating anthesis, whereas applications made $\approx 1$ week after planting (Group 1) enhanced yield the most. As this group was the first to receive $\mathrm{GA}_{3}$ application, this result suggests that plants are more responsive at a younger age.

While our results suggested efficacy of $\mathrm{GA}_{3}$ at $400 \mathrm{mg} \cdot \mathrm{liter}^{-1}$, neither the optimum rate nor effectiveness under a range of temperatures were evaluated. The lack of significant stem length or diameter differences between $\mathrm{GA}_{3}$-treated and control plants indicate that stem quality was unaffected by $\mathrm{GA}_{3}$ applications. These data support applying gibberellin as a practical and effective component of a production program for this crop, given the improvement observed in flowering response.
Exogenous $\mathrm{GA}_{3}$ application accelerated flowering of this crop under cool, long-day, greenhouse conditions and may serve to enhance scheduling and reduce net energy inputs to produce this hybrid without compromising quality. The increase in yield, related to early application, would be the greatest benefit of this treatment.

\section{Literature Cited}

Armitage, A. 1993. Specialty cut flowers. Timber Press, Portland, Ore.

New World Plants. 1992. Limonium hybrids. Technical Bul. 1992. New World Plants, Escondito, Calif.

Semeniuk, P. and D.T. Krizek. 1972. Long days and cool night temperatures increase flowering of greenhouse grown Limonium cultivars. HortScience 7:293.

Shilo, R. 1977. Influence of GA and number of cold days on flowering of statice 'Midnight Blue', $p$. 26-40. In: Annu. Rpt. Dept. Ornamental Hort., Hebrew Univ., Rehovot, Israel. (Abstr.)

Shilo, R. and E. Zamski. 1985. Limonium sinuatum, p. 292-301. In: A.H. Halevy (ed.). Handbook of flowering. vol. 3. CRC Press, Boca Raton, Fla.

Wilfret, G.J. and J.C. Raulston. 1975. Acceleration of flowering of statice (Limonium sinuatum Mill.) by gibberellic acid $\left(\mathrm{GA}_{3}\right)$. HortScience 10:37-38. 